Tetrahedron

journal homepage: www.elsevier.com

\title{
Enantioselective oxidative-coupling of polycyclic phenols
}

\author{
Shinobu Takizawa ${ }^{\mathrm{a}}$, Junpei Kodera ${ }^{\mathrm{a}}$, Yasushi Yoshida ${ }^{\mathrm{a}}$, Makoto Sako ${ }^{\mathrm{a}}$, Stefanie Breukers ${ }^{\mathrm{a}, \mathrm{b}}$, Dieter Enders ${ }^{\mathrm{b}}$ \\ and Hiroaki Sasai ${ }^{*}$ \\ ${ }^{a}$ The Institute of Scientific and Industrial Research (ISIR), Osaka University, Mihogaoka, Ibaraki-shi, Osaka 567-0047, Japan \\ ${ }^{b}$ Institute of Organic Chemistry, RWTH Aachen University, Landoltweg 1, 52074 Aachen, Germany
}

\section{ARTICLE INFO}

Article history:

Received

Received in revised form

Accepted

Available online

Keywords:

Enantioselective

Vanadium

Polycyclic phenol

Oxidative-coupling

\section{ABSTRACT}

Enantioselective oxidative-coupling of polycyclic phenols such as 2-anthracenol, 9- or 3phenanthrol, and 5-chrysenol was established by using vanadium(V/IV) catalysis under air or $\mathrm{O}_{2}$ as a co-oxidant. In the vanadium catalyzed reaction, the corresponding coupling products were obtained in good to excellent yields with up to $93 \%$ enantiomeric excess.

2013 Elsevier Ltd. All rights reserved.

\section{Introduction}

The preparation of optically pure 1,1'-bi-2-naphthol (BINOL) and its derivatives is of great importance because of their wide utility in asymmetric synthesis. ${ }^{1}$ Among the synthetic methods to access enantiomerically pure BINOLs, the asymmetric and catalytic oxidative coupling of 2-naphthols is one of the most straightforward processes. ${ }^{2,3}$ Polycyclic biphenols such as bianthracenol 1a, biphenanthrols 1b-c, and bichrysenol 1d are also useful as chiral BINOL derivatives (Fig. 1). ${ }^{4-6}$ Despite their potential applications, no efficient enantioselective catalytic oxidative-coupling of the polycyclic phenols $\mathbf{2}$ to yield $\mathbf{1}$ has been achieved due to the facile over-oxidation of the product and/or side-reaction of the substrate.

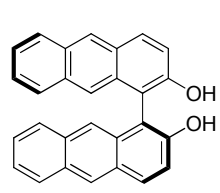

$1 \mathrm{a}$

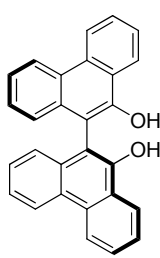

1b

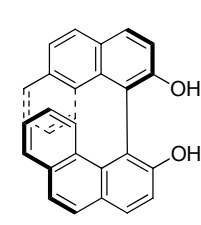

1c

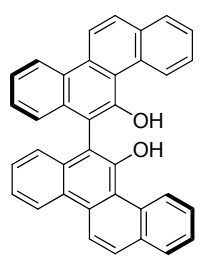

1d
Fig. 1. Chiral polycyclic biphenol derivatives.

Enantioselective vanadium-mediated oxidative couplings, which occur via a favorable one-electron phenolic oxidation, proceed under mild reaction conditions and tolerate several functional groups; this has a further advantage that only water is formed as a side product. ${ }^{3}$ Previously, we reported a dinuclear vanadium(V) complex $\left(R_{\mathrm{a}}, S, S\right)-\mathbf{3}$ possessing two active sites in a single molecule, which promotes the enantioselective oxidative coupling of 2-naphthols under air as a co-oxidant through a dual activation mechanism. ${ }^{3 \mathrm{~m}-\mathrm{o}}$

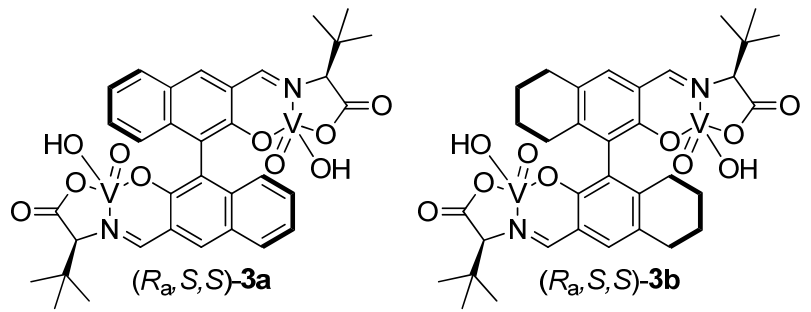

Fig. 2. Dinuclear vanadium(V) complexes, $\left(R_{\mathrm{a}}, S, S\right)-\mathbf{3}$.

We envisioned that, under the mild reaction conditions, the dinuclear vanadium(V) complex could work as a chiral catalyst for the oxidative-coupling of these easily oxidized polycyclic phenols 2 without the formation of any side-products. In this manuscript, we describe the first enantioselective catalytic coupling of 2-anthracenol (2a), 3-phenanthrol (2c), and 5chrysenol (2d), and the efficient enantioselective catalytic coupling of 9-phenanthrol (2b) ${ }^{30}$ using chiral vanadium(V) complexes, in detail.

* Corresponding author. Tel.: +81-6-6879-8465; fax: +81-6-6879-8469; e-mail: sasai@sanken.osaka-u.ac.jp 


\section{Results and discussion}

\subsection{Enantioselective coupling of anthracenol $\mathbf{2 a}$}

Table 1. Enantioselective coupling of 2-anthracenol (2a).

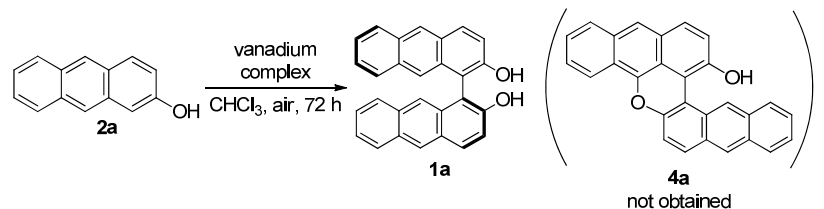

\begin{tabular}{ccccc}
\hline Entry & $\begin{array}{c}\text { Vanadium complex } \\
(\mathrm{mol} \%)\end{array}$ & $\begin{array}{c}\text { Temp } \\
\left({ }^{\circ} \mathrm{C}\right)\end{array}$ & $\begin{array}{c}\text { Yield of isolated } \\
\text { product } \%\end{array}$ & ee \% ${ }^{\mathrm{a}}$ \\
\hline 1 & $\left(R_{\mathrm{a}}, S, S\right)-\mathbf{3 a}(5)$ & -10 & 80 & $85(>99)^{\mathrm{b}}$ \\
2 & $\left(R_{\mathrm{a}}, S, S\right)-3 \mathbf{b}(5)$ & -10 & 91 & 51 \\
3 & $\left(R_{\mathrm{a}}, S, S\right)-3 \mathbf{a}(5)$ & -20 & 60 & 74 \\
4 & $\left(R_{\mathrm{a}}, S, S\right)-3 \mathbf{b}(5)$ & -20 & 80 & 49 \\
5 & $(S)-5 \mathbf{a}(10)$ & -10 & 47 & 29 \\
\hline
\end{tabular}

${ }^{a}$ Determined using HPLC (Daicel Chiralpak AD-H). ${ }^{b}$ After a single recrystallization

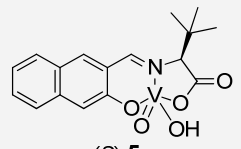

(S)-5a

In 2013, Takahashi reported the first catalytic oxidative coupling of 2-anthracenol (2a) with $5 \mathrm{~mol} \%$ of $\mathrm{MnI}_{2}$, yielding bianthracenol 1a in 74\% yield. ${ }^{4 b}$ However, no catalytic asymmetric synthesis of $\mathbf{1 a}$ has been achieved. Furthermore, 1a is easily over-oxidized to the ether derivative $4 \mathbf{a}$. To our delight, $\left(R_{\mathrm{a}}, S, S\right)$-3a was found to promote the oxidative coupling reaction of 2a to yield 1a without the formation of $4 \mathbf{a}$ (Table 1). The reaction with $5 \mathrm{~mol} \%$ of $\left(R_{\mathrm{a}}, S, S\right)-3 \mathrm{a}$ at $-10{ }^{\circ} \mathrm{C}$ under air produced 1a in $80 \%$ yield with $85 \%$ ee (entry 1 ). The lowering of the reaction temperature to $-20{ }^{\circ} \mathrm{C}$ or the use of the complex $\left(R_{\mathrm{a}}, S, S\right)$-3b with $\mathrm{H}_{8}$-BINOL backbone led to reduction in the enantioselectivity of the product (entries 2-4). The reaction rate of mononuclear vanadium complex $(S)-5 \mathbf{a}$, which has only one catalytically active center, was quite low in comparison with that of $\left(R_{\mathrm{a}}, S, S\right)-\mathbf{3 a}$, while using $10 \mathrm{~mol} \%$ of the catalyst (S)-5a (entry $5)$. The higher reaction rate and enantioselectivity using dinuclear complex $\left(R_{\mathrm{a}}, S, S\right)$-3a than those obtained using a mononuclear $(S)$-5a catalyzed reaction are attributable to the simultaneous activation $^{3 \mathrm{~m}-\mathrm{o}}$ of two molecules of 2a. Optically pure $\mathbf{1 a}$ could be obtained after a recrystallization from hexane $/ \mathrm{CH}_{2} \mathrm{Cl}_{2}$ (entry 1 ).
2.2. Enantioselective coupling of phenanthrols $2 \boldsymbol{b}$ and $2 \boldsymbol{c}$

An effective and enantioselective synthesis of 9,9'-bi(10phenanthrol) (1b) via the oxidative coupling of 9-phenanthrol (2b) has also been a challenge in the oxidative-coupling reactions because $\mathbf{2 b}$ is easily oxidized to the corresponding quinone derivative, phenanthrene-9,10-dione $(\mathbf{4 b}) .{ }^{5}$ The results of coupling 2b using vanadium complexes are shown in Table 2. The dinuclear vanadium catalyst $\left(R_{\mathrm{a}}, S, S\right)-\mathbf{3 a}$ was found to promote the oxidative coupling reaction of $\mathbf{2} \mathbf{b}$ to give $\mathbf{1 b}$ in high yields without the formation of $\mathbf{4 b}$. Among the reaction solvents studied, $\mathrm{CH}_{2} \mathrm{Cl}_{2}$ provided the highest reaction rate with high enantioselectivity, producing biphenanthrol $\mathbf{1 b}$ in $94 \%$ yield with $88 \%$ ee (entry 4 ). Although the reaction proceeded under air, the ee of $\mathbf{1 b}$ decreased slightly to $76 \%$ (entry 6 ). At $-10{ }^{\circ} \mathrm{C}$ under $\mathrm{O}_{2}$, the reaction with $5 \mathrm{~mol} \%$ of $\left(R_{\mathrm{a}}, S, S\right)-\mathbf{3 a}$ produced $\mathbf{1 b}$ in quantitative yield and with $93 \%$ ee (entry 8). The enantioselective coupling of $\mathbf{2 b}$ on a gram scale $(6.0 \mathrm{~g}$, entry 9$)$ led to $\mathbf{1 b}$ in $90 \%$ yield with $90 \%$ ee. Optically pure $\mathbf{1 b}$ could be obtained after a single recrystallization from hexane/acetone (entries 8 and 9).

Next, we focused on the coupling reaction of 3-phenanthrol (2c) to give 4,4'-bi(3-phenanthrol) (1c), which could be readily applied to construct hetero[7] helicenes. ${ }^{5 \mathrm{~m}}$ During our screening of conditions (Table 3), the dinuclear vanadium complex $\left(R_{\mathrm{a}}, S, S\right)-3 \mathbf{b}$ in $\left(\mathrm{CH}_{2} \mathrm{Cl}\right)_{2}$ was found to exhibit moderate asymmetric induction to produce $1 \mathrm{c}$ in $32 \%$ yield with $65 \%$ ee (entry 3). The yield of 1c was increased to $48 \%$ at $60{ }^{\circ} \mathrm{C}$; however, the enantioselectivity decreased to $43 \%$ ee (entry 6 ). Insufficient improvement in chemical yield was observed even when a quantitative amount of the vanadium complex was employed (entry 9). A product inhibition might be responsible for the low conversion of the coupling of $\mathbf{2 c}$. To establish the reason for the low conversion of $\mathbf{2 c}$, the reactions of 2-naphthol (2e) or 6-methoxy-2-naphthol (2f) in the presence of 1c or $2 \mathbf{c}$ were investigated (Scheme 1). After mixing $\left(R_{\mathrm{a}}, S, S\right)-3 \mathbf{b}$ and biphenanthrol $1 \mathrm{c}$ in $\left(\mathrm{CH}_{2} \mathrm{Cl}\right)_{2}$ under air for $24 \mathrm{~h}$, 2-naphthol (2e) was added to the reaction mixture. The coupling reaction of $2 \mathrm{e}$ proceeded smoothly to give BINOL 1e in $86 \%$ yield, and biphenanthrol 1c was recovered quantitatively (eq 1). Similarly, catalyst $\left(R_{\mathrm{a}}, S, S\right)-\mathbf{3 b}$ was mixed with phenanthrol $\mathbf{2 c}$ for $24 \mathrm{~h}$, followed by the addition of 2-naphthol (2e); however, almost no BINOL 1e was formed, and biphenanthrol 1c was obtained in $30 \%$ yield (eq 2). When 6-methoxy-2-naphthol (2f), a highly reactive substrate for the coupling, was added after mixing catalyst $\left(R_{\mathrm{a}}, S, S\right)-\mathbf{3 b}$ and phenanthrol $\mathbf{2 c}$ for $24 \mathrm{~h}$, the coupling

Table 2. Enantioselective coupling of 9-phenanthrol (2b).
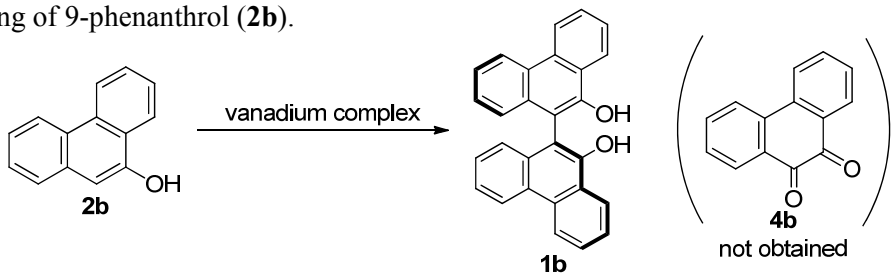

\begin{tabular}{|c|c|c|c|c|c|c|c|}
\hline Entry & $\begin{array}{l}\text { Vanadium complex } \\
(\mathrm{mol} \%)\end{array}$ & Solvent & Atmosphere & $\begin{array}{l}\text { Temp } \\
\left({ }^{\circ} \mathrm{C}\right)\end{array}$ & $\begin{array}{l}\text { Time } \\
\text { (h) }\end{array}$ & Yield of isolated product $\%$ & ee $\%^{\mathrm{a}}$ \\
\hline 1 & $\left(R_{\mathrm{a}}, S, S\right)-\mathbf{3 a}(5)$ & $\mathrm{MeCN}$ & $\mathrm{O}_{2}$ & -5 & 70 & 92 & 89 \\
\hline 2 & $\left(R_{\mathrm{a}}, S, S\right)-\mathbf{3 a}(5)$ & Toluene & $\mathrm{O}_{2}$ & -5 & 72 & 80 & 86 \\
\hline 3 & $\left(R_{\mathrm{a},}, S, S\right)-\mathbf{3 a}(5)$ & $\mathrm{CHCl}_{3}$ & $\mathrm{O}_{2}$ & -5 & 60 & 90 & 54 \\
\hline 4 & $\left(R_{\mathrm{a}}, S, S\right)-\mathbf{3 a}(5)$ & $\mathrm{CH}_{2} \mathrm{Cl}_{2}$ & $\mathrm{O}_{2}$ & -5 & 36 & 94 & 88 \\
\hline 5 & $\left(R_{\mathrm{a}}, S, S\right)-\mathbf{3 a}(5)$ & $\mathrm{CH}_{2} \mathrm{Cl}_{2}$ & $\mathrm{O}_{2}$ & 0 & 24 & 92 & 84 \\
\hline 6 & $\left(R_{\mathrm{a}}, S, S\right)-\mathbf{3 a}(5)$ & $\mathrm{CH}_{2} \mathrm{Cl}_{2}$ & Air & -5 & 74 & 80 & 76 \\
\hline 7 & $(S)-5 \mathbf{a}(10)$ & $\mathrm{CH}_{2} \mathrm{Cl}_{2}$ & $\mathrm{O}_{2}$ & -10 & 48 & 29 & $10^{\mathrm{b}}$ \\
\hline 8 & $\left(R_{\mathrm{a}}, S, S\right)-\mathbf{3 a}(5)$ & $\mathrm{CH}_{2} \mathrm{Cl}_{2}$ & $\mathrm{O}_{2}$ & -10 & 48 & $100(80)^{\mathrm{c}}$ & $93(>99)^{\mathrm{c}}$ \\
\hline $9^{\mathrm{d}}$ & $\left(R_{\mathrm{a}}, S, S\right)-\mathbf{3 a}(5)$ & $\mathrm{CH}_{2} \mathrm{Cl}_{2}$ & $\mathrm{O}_{2}$ & -10 & 48 & $90(79)^{\mathrm{c}}$ & $90(>99)^{\mathrm{c}}$ \\
\hline
\end{tabular}

${ }^{a}$ Determined using HPLC (Daicel Chiralpak AD-H). ${ }^{\mathrm{b}}$ The major product has $(R)$-configuration. ${ }^{\mathrm{c}} \mathrm{After}$ a single recrystallization. ${ }^{\mathrm{d}} 6.0 \mathrm{~g}$ scale. 
Table 3. Enantioselective coupling of 3-phenanthrol (2c).

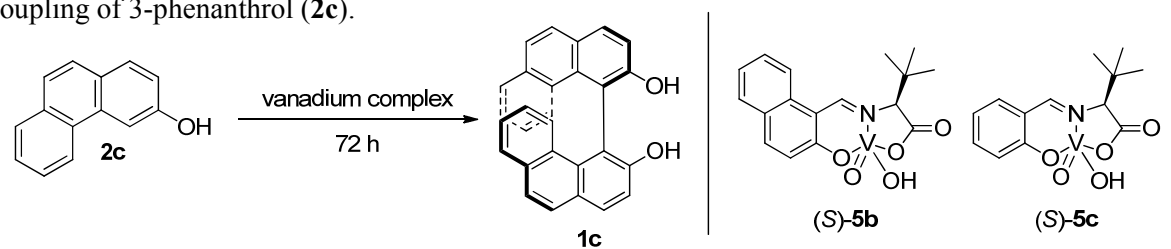

\begin{tabular}{|c|c|c|c|c|c|c|}
\hline Entry & Vanadium complex (mol \%) & Solvent & Atmosphere & Temp $\left({ }^{\circ} \mathrm{C}\right)$ & Yield of isolated product $\%$ & ee $\%{ }^{a}$ \\
\hline 1 & $\left(R_{\mathrm{a}}, S, S\right)-\mathbf{3 a}(5)$ & $\mathrm{CH}_{2} \mathrm{Cl}_{2}$ & $\mathrm{O}_{2}$ & 10 & 39 & 40 \\
\hline 2 & $\left(R_{\mathrm{a}}, S, S\right)-\mathbf{3 b}(5)$ & $\mathrm{CH}_{2} \mathrm{Cl}_{2}$ & $\mathrm{O}_{2}$ & 10 & 30 & 42 \\
\hline 3 & $\left(R_{\mathrm{a}}, S, S\right)-\mathbf{3 b}(5)$ & $\left(\mathrm{CH}_{2} \mathrm{Cl}\right)_{2}$ & $\mathrm{O}_{2}$ & 10 & 32 & 65 \\
\hline 4 & $\left(R_{\mathrm{a}}, S, S\right)-\mathbf{3 b}(5)$ & Toluene & $\mathrm{O}_{2}$ & 10 & 15 & 20 \\
\hline 5 & $\left(R_{\mathrm{a}}, S, S\right)-3 \mathbf{b}(5)$ & $\left(\mathrm{CH}_{2} \mathrm{Cl}\right)_{2}$ & $\mathrm{O}_{2}$ & -10 & 9 & 67 \\
\hline 6 & $\left(R_{\mathrm{a}}, S, S\right)-\mathbf{3 b}(5)$ & $\left(\mathrm{CH}_{2} \mathrm{Cl}\right)_{2}$ & $\mathrm{O}_{2}$ & 60 & 48 & 43 \\
\hline 7 & $\left(R_{\mathrm{a}}, S, S\right)-\mathbf{3 b}(5)$ & $\mathrm{CHCl}_{3}$ & Air & 10 & 30 & 69 \\
\hline 8 & $\left(R_{\mathrm{a}}, S, S\right)-\mathbf{3 b}(5)$ & $\mathrm{CHCl}_{3}$ & $\mathrm{O}_{2}$ & 10 & 32 & 68 \\
\hline 9 & $\left(R_{\mathrm{a}}, S, S\right)-\mathbf{3 b}(100)$ & $\mathrm{CHCl}_{3}$ & $\mathrm{O}_{2}$ & 10 & 45 & 67 \\
\hline 10 & $(S)-5 \mathbf{a}(10)$ & $\left(\mathrm{CH}_{2} \mathrm{Cl}\right)_{2}$ & $\mathrm{O}_{2}$ & 10 & 25 & 10 \\
\hline 11 & $(S)-\mathbf{5 b}(10)$ & $\left(\mathrm{CH}_{2} \mathrm{Cl}\right)_{2}$ & $\mathrm{O}_{2}$ & 10 & 32 & 12 \\
\hline 12 & $(S)-5 \mathbf{c}(10)$ & $\left(\mathrm{CH}_{2} \mathrm{Cl}\right)_{2}$ & $\mathrm{O}_{2}$ & 10 & 28 & Rac \\
\hline
\end{tabular}

${ }^{a}$ Determined using HPLC (Daicel Chiralpak OD-H)

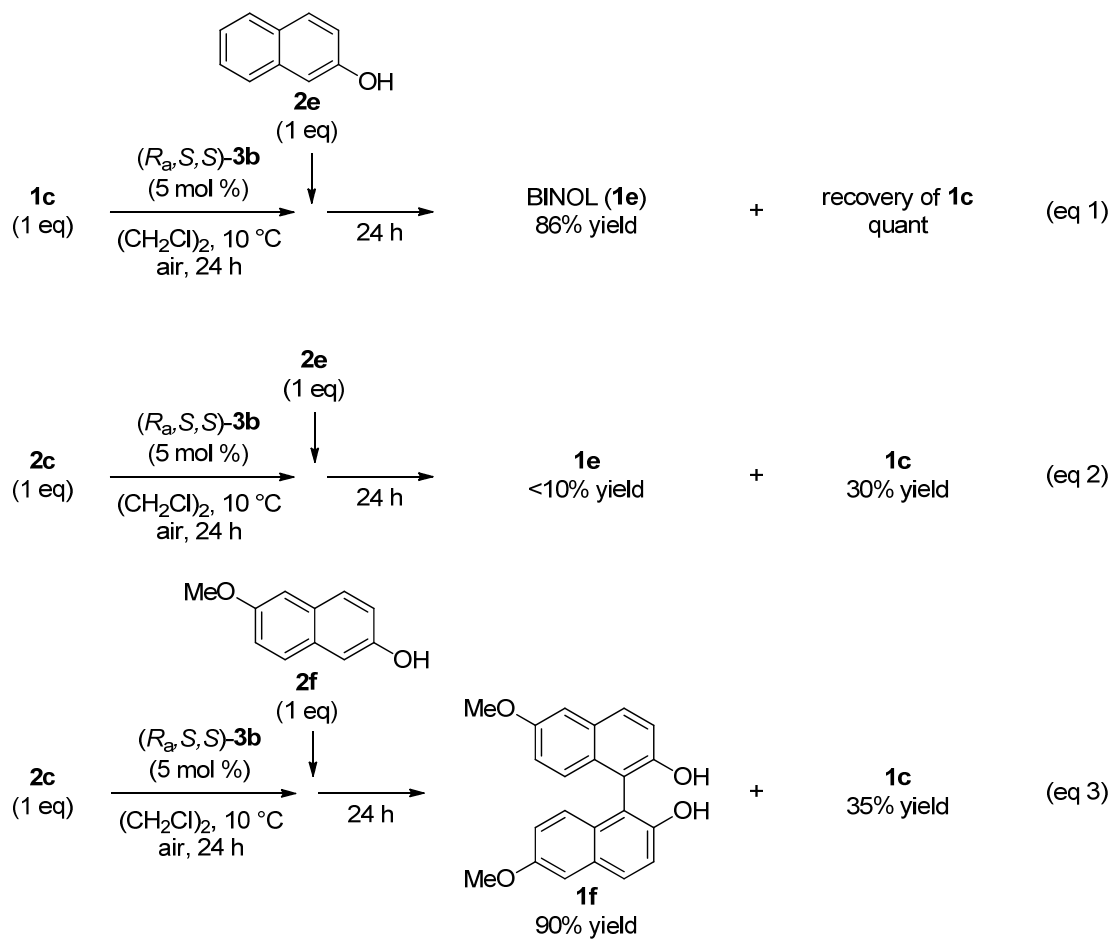

Scheme 1. Coupling of 2-naphthols $2 \mathbf{e}$ or $2 \mathbf{f}$ in the presence of 1 eq of biphenanthrol $1 \mathbf{c}$ or phenanthrol $\mathbf{2 c}$.

products 1f and 1c were obtained in $90 \%$ yield and $35 \%$ yield respectively (eq 3 ). In all cases, no hetero-cross-coupling product was formed. ${ }^{3 \mathrm{n}}$ The reason for the low conversion of $\mathbf{2 c}$ remains unclear; however, given the results of the coupling reactions, our previously proposed reaction mechanism ${ }^{3 \mathrm{~m}-\mathrm{o}}$ might be in agreement with an intramolecular coupling as shown in Scheme 2 . The dinuclear vanadium(V) complex reacts with two molecules of $2 \mathrm{c}$ resulting in Ia. The C-1 position of the substrates approaches each other by the rotation of the binaphthyl axis yielding $\mathbf{I b}$, which is then intramolecularly coupled after a single electron transfer to a vanadium(V) species III via intermediate II. However, intermediate III would be very stable, resulting in the slow release of 1c from III. As a result, low conversion was observed when $2 \mathbf{c}$ was used as a substrate for the homo-coupling using catalyst $\left(R_{\mathrm{a}}, S, S\right)-\mathbf{3 b}$.

\subsection{Enantioselective coupling of chrysenol $\mathbf{2 d}$}

Bichrysenol 1d is expected to create an effective asymmetric environment because of the additional aromatic ring adjacent to the hydroxy group. ${ }^{1}$ The oxidative coupling of 5-chrysenol (2d) was also conducted using dinuclear vanadium(V) complexes $\left(R_{\mathrm{a}}, S, S\right)-3$ (Table 4). However, racemic 1d was obtained when 5 mol \% of $\left(R_{\mathrm{a}}, S, S\right)$-3a or $\mathbf{3 b}$ was used at $-10{ }^{\circ} \mathrm{C}$ under $\mathrm{O}_{2}$ (entry 1). These results may be attributed to the steric obstruction close to the reaction site of the dinuclear complex. Therefore, we tested mononuclear vanadium complexes $\mathbf{5}$ which possess less steric hindrance. As expected, the mononuclear vanadium complexes could promote the coupling of $\mathbf{2 d}$ enantioselectively. In this coupling reaction, the aromatic substitutions on catalysts $\mathbf{5}$ made a significant impact on the enantioselectivity of 1d. As shown in 
Table 4, catalysts $(S)-\mathbf{5 b}$ and $\mathbf{5 d}$, bearing a 5- or 6-substituent on the aromatic ring of the catalyst, exhibited good asymmetric induction in 1d (entries 3 and $5,71 \%$ ee and $61 \%$ ee, respectively). In contrast, 3- and/or 4-mono- or disubstituted catalysts gave 1d with $<30 \%$ ee (entries 2 and 6-8). Among the reaction conditions we screened, mononuclear vanadium catalyst 5b in $\mathrm{CH}_{2} \mathrm{Cl}_{2}$ led to coupling with the highest ee (75\%). Finally, optically pure 1d was readily obtained by a recrystallization from a hexane $/ \mathrm{CH}_{2} \mathrm{Cl}_{2}$ mixed solvent system (entry 11 ).

\section{Application of coupling product 1 to enantioselective direct aza-hetero-Diels-Alder reaction}

Chiral phosphoric acids have emerged as a class of powerful organocatalysts ${ }^{7}$ for the activation of imine functional groups, resulting in a number of asymmetric additions of various nucleophiles to imines. In 2006, Gong ${ }^{8 a}$ and Rueping ${ }^{8 b}$ independently reported the direct aza-hetero-Diels-Alder reaction of 2-cyclohexenone (7) with aldimines 8 to produce

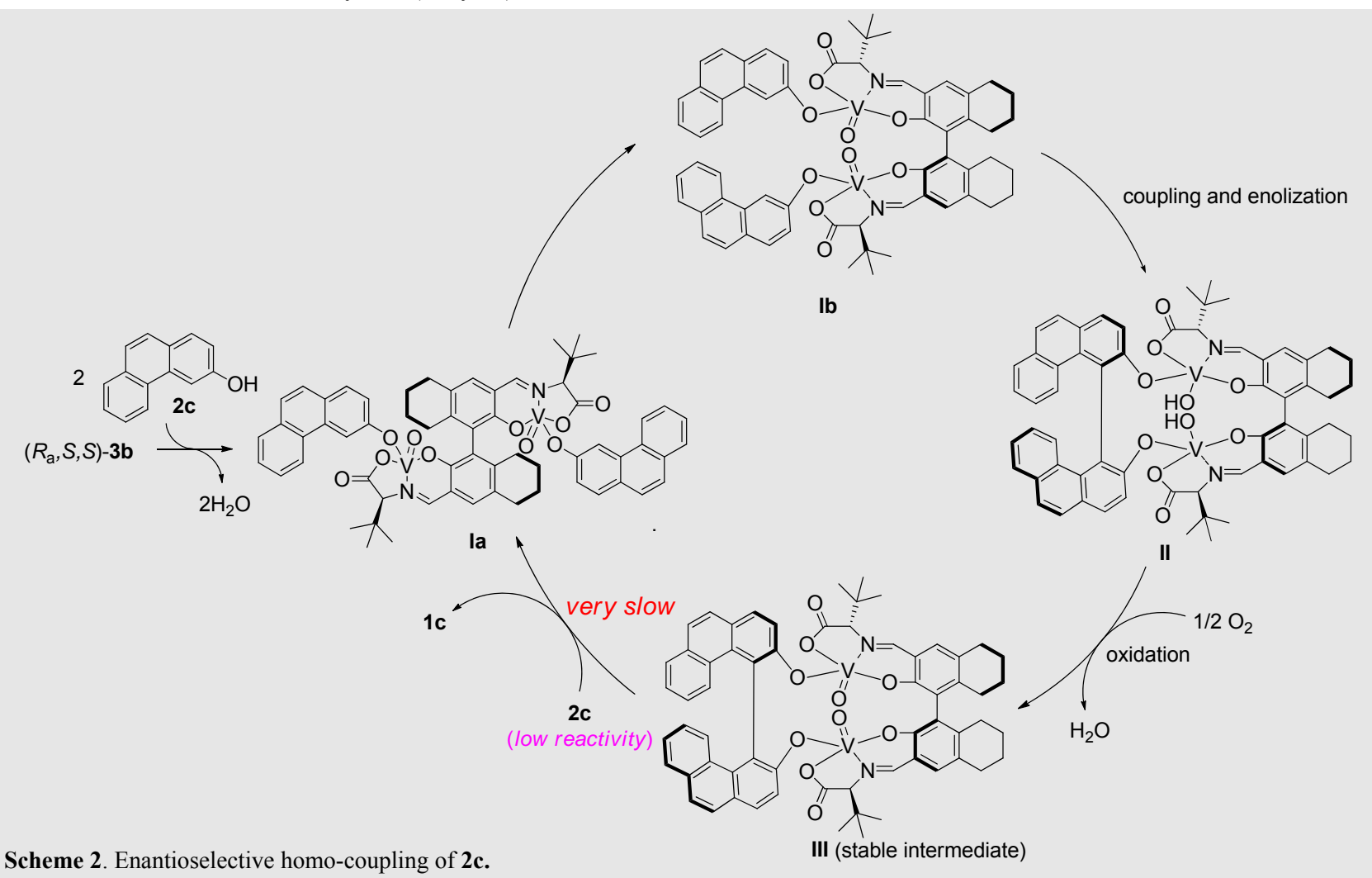

Table 4. Enantioselective coupling of 5-chrysenol (2d).
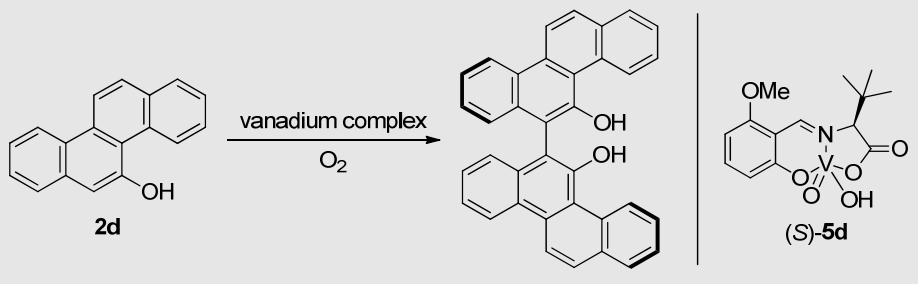

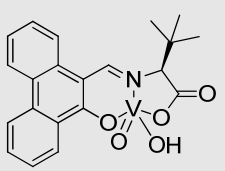

(S)-5e

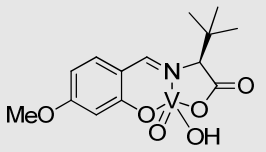

$(S)-5 f$

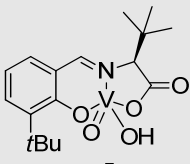

(S)-5g

$1 d$

\begin{tabular}{|c|c|c|c|c|c|c|}
\hline Entry & Vanadium complex (mol \%) & Solvent & Temp $\left({ }^{\circ} \mathrm{C}\right)$ & Time $(\mathrm{h})$ & Yield of isolated product $\%$ & ee $\%{ }^{a}$ \\
\hline 1 & $\left(R_{\mathrm{a}}, S, S\right)-\mathbf{3 a}(5)$ or $\mathbf{3 b}(5)$ & $\mathrm{CH}_{2} \mathrm{Cl}_{2}$ & -10 & 24 & 54 or 55 & $\mathrm{Rac}$ \\
\hline 2 & $(S)-5 \mathbf{a}(10)$ & $\mathrm{CH}_{2} \mathrm{Cl}_{2}$ & -10 & 24 & 67 & 30 \\
\hline 3 & $(S)-5 \mathbf{b}(10)$ & $\mathrm{CH}_{2} \mathrm{Cl}_{2}$ & -10 & 24 & 55 & 71 \\
\hline 5 & $(S)-5 d(10)$ & $\mathrm{CH}_{2} \mathrm{Cl}_{2}$ & -10 & 24 & 32 & 61 \\
\hline 6 & $(S)-5 \mathbf{e}(10)$ & $\mathrm{CH}_{2} \mathrm{Cl}_{2}$ & -10 & 24 & 47 & $9^{\mathrm{b}}$ \\
\hline 7 & $(S)-\mathbf{5 f}(10)$ & $\mathrm{CH}_{2} \mathrm{Cl}_{2}$ & -10 & 24 & 48 & $20^{\mathrm{b}}$ \\
\hline 8 & $(S)-5 g(10)$ & $\mathrm{CH}_{2} \mathrm{Cl}_{2}$ & -10 & 24 & 43 & $27^{\mathrm{b}}$ \\
\hline 9 & $(S)-5 \mathbf{b}(10)$ & $\mathrm{CH}_{2} \mathrm{Cl}_{2}$ & -20 & 24 & 52 & 68 \\
\hline 10 & $(S)-5 \mathbf{b}(10)$ & $\mathrm{CH}_{2} \mathrm{Cl}_{2}$ & Rt & 24 & 54 & 25 \\
\hline 11 & $(S)-\mathbf{5 b}(10)$ & $\mathrm{CH}_{2} \mathrm{Cl}_{2}$ & -10 & 36 & 83 & $75(>99)^{\mathrm{c}}$ \\
\hline 12 & $(S)-\mathbf{5 b}(10)$ & $\mathrm{CHCl}_{3}$ & -10 & 36 & 36 & 63 \\
\hline 13 & $(S)-5 \mathbf{b}(10)$ & $\mathrm{CCl}_{4}$ & -10 & 36 & 55 & 64 \\
\hline 14 & $(S)-\mathbf{5 b}(10)$ & Toluene & -10 & 36 & 45 & 24 \\
\hline
\end{tabular}

${ }^{a}$ Determined using HPLC (Daicel Chiralpak AD-H). ${ }^{b}$ The major product has $(R)$-configuration. ${ }^{c}$ After a single recrystallization. 
Table 5. Direct organocatalytic enantioselective Diels-Alder reaction of 2-cyclohexenone (7) and aldimines 8.

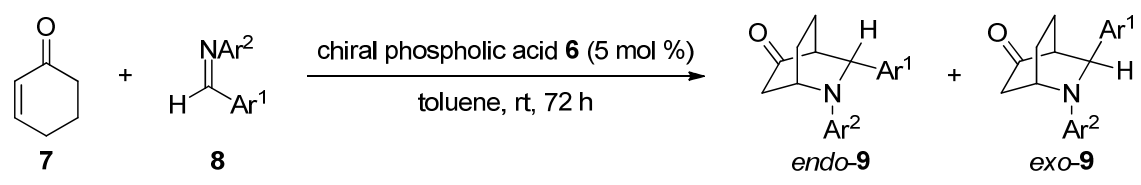

\begin{tabular}{|c|c|c|c|c|c|c|}
\hline Entry & Phosphoric acids & $\mathrm{Ar}^{1}$ & $\mathrm{Ar}^{2}$ & 8 & $\begin{array}{c}\text { Yield of isolated product \% } \\
\text { (ratio endo/exo) }\end{array}$ & ee $\%$ of endo \\
\hline 1 & $6 \mathbf{a}$ & $\mathrm{Ph}$ & $4-\mathrm{Br}_{-} \mathrm{C}_{6} \mathrm{H}_{4}$ & 8a & $80(60 / 40), 9 a$ & Rac \\
\hline 2 & 6b & $\mathrm{Ph}$ & $4-\mathrm{Br}-\mathrm{C}_{6} \mathrm{H}_{4}$ & $8 \mathbf{a}$ & $52(67 / 32), 9 a$ & 25 \\
\hline 3 & $6 c$ & $\mathrm{Ph}$ & $4-\mathrm{Br}-\mathrm{C}_{6} \mathrm{H}_{4}$ & $\mathbf{8 a}$ & $63(60 / 40), 9 a$ & Rac \\
\hline 4 & 6d & $\mathrm{Ph}$ & $4-\mathrm{Br}-\mathrm{C}_{6} \mathrm{H}_{4}$ & $\mathbf{8 a}$ & $54(78 / 22), 9 a$ & 53 \\
\hline 5 & $6 e$ & $\mathrm{Ph}$ & $4-\mathrm{Br}-\mathrm{C}_{6} \mathrm{H}_{4}$ & $\mathbf{8 a}$ & $50(69 / 31), 9 a$ & Rac \\
\hline 6 & 6d & $\mathrm{Ph}$ & 4-MeO- $\mathrm{C}_{6} \mathrm{H}_{4}$ & $8 b$ & $74^{\mathrm{b}}(79 / 21), 9 \mathbf{b}$ & 36 \\
\hline 7 & 6d & 2-naphthyl & $4-\mathrm{MeO}-\mathrm{C}_{6} \mathrm{H}_{4}$ & $8 c$ & $92(77 / 23), 9 c$ & 34 \\
\hline 8 & 6d & $2-\mathrm{F}-\mathrm{C}_{6} \mathrm{H}_{4}$ & $4-\mathrm{Br}-\mathrm{C}_{6} \mathrm{H}_{4}$ & 8d & $51(75 / 25), 9 d$ & 46 \\
\hline
\end{tabular}<smiles>O=P(O)(O)OC1=CC=CC2=Cc3ccccc3C=C1/C2=C1/C=Cc2cc3ccccc3cc21</smiles>

$6 \mathbf{a}$<smiles>O=P(O)(Oc1ccccc1)Oc1c(-c2c(-c3ccccc3)c3ccccc3c3ccccc23)c2ccccc2c2ccccc12</smiles>

6b

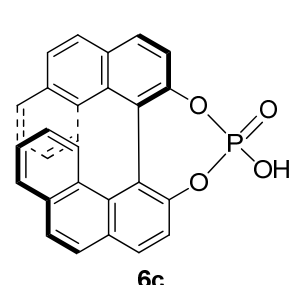

$6 c$<smiles></smiles>

6d isoquinuclidines. To confirm the ability of polycyclic biphenols $\mathbf{1}$ in asymmetric catalysis, the corresponding chiral phosphoric acids 6 were prepared from the coupling product $\mathbf{1}$ and then tested on the aza-hetero-Diels-Alder reaction (Table 5). ${ }^{8 a}$ Chiral phosphoric acids $\mathbf{6 a}, \mathbf{6 c}$, and $\mathbf{6 e}$ could promote the reaction, but only afforded the racemic product $9 \mathrm{a}$ (entries 1,3 , and 5). The 9,9'-bi(10-phenanthrol)- and bichrysenol-derived catalysts $\mathbf{6 b}$ and 6d could provide better asymmetric environments than those of catalysts $\mathbf{6 a}, \mathbf{6 c}$, and $\mathbf{6 e}$ because of the additional two or four aromatic rings near the phosphoric acid group, leading to the formation of product 9a with up to $53 \%$ ee (entry 4). In comparison with the best result obtained using catalyst $6 \mathbf{f}$, reported by Rueping (Scheme 3), ${ }^{8 b}$ our catalyst 6d would still need an increased bulk to create an efficient chiral environment for the aza-hetero-Diels-Alder reaction.
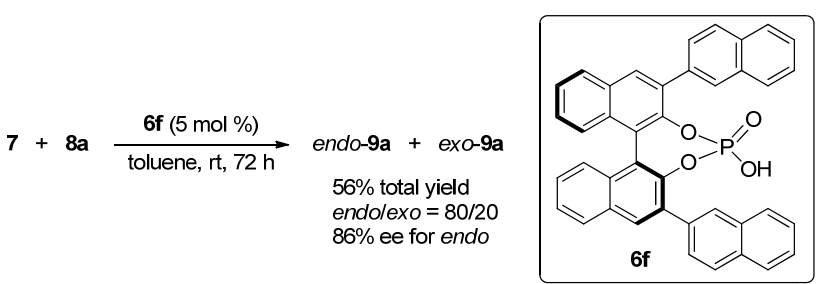

Scheme 3. Enantioselective Diels-Alder reaction reported by Rueping. ${ }^{8 b}$

\section{Transformation of polycyclic biphenol}

In order to improve the chiral catalyst efficiency of the polycyclic biphenol, various transformations of $\mathbf{1 b}$ were tested (Scheme 4). The reaction of $\mathbf{1 b}$ using $\mathrm{PtO}_{2}(1 \mathrm{eq})$ in glacial acetic acid under $\mathrm{H}_{2}(1 \mathrm{~atm})$ at room temperature led to complete conversion to give $\mathrm{H}_{16}$-biphenanthrol $\mathbf{1 0}$ in $80 \%$ yield. ${ }^{9}$ The methyl capped biphenanthrol $\mathbf{1 1}^{\text {5a }}$ underwent bromination by using $N$-bromosuccinimide (NBS), providing the 6,6'dibrominated compound $\mathbf{1 2}$ quantitatively. The methyl capped dibromobiphenanthrol $\mathbf{1 2}$ could be a versatile intermediate for further derivatization. Thus, 12 was treated with $\mathrm{Pd}\left(\mathrm{PPh}_{3}\right)_{4}$,
$\mathrm{PhB}(\mathrm{OH})_{2}$, and $\mathrm{Na}_{2} \mathrm{CO}_{3}$ in 1,2-dimethoxyethane (DME) at reflux temperature providing 14 . The methoxy derivatives were easily deprotected in the presence of $\mathrm{BBr}_{3}$, which provided diols 13 or $\mathbf{1 5}$ in good yields.

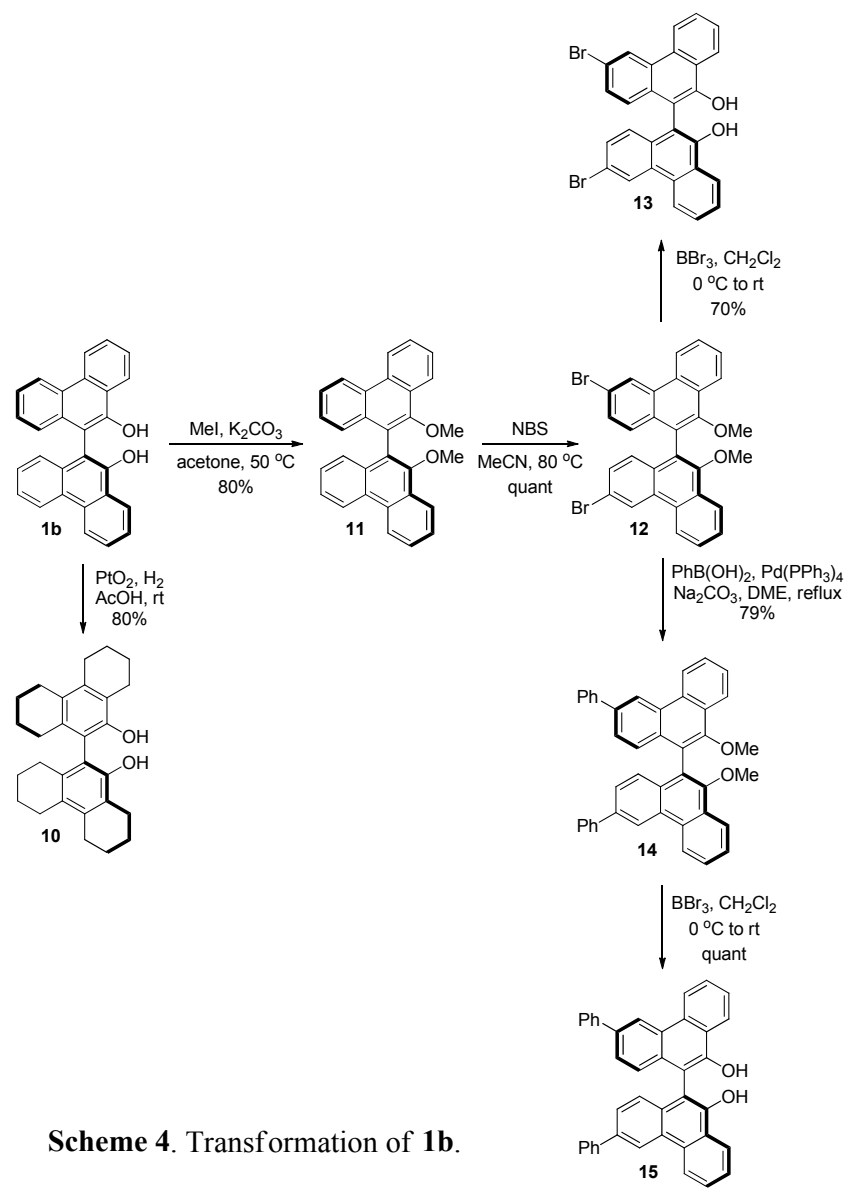




\section{Conclusions}

We have developed a vanadium-mediated enantioselective catalytic oxidative-coupling of polycyclic phenols 2; various phenols were successfully employed with 5 or $10 \mathrm{~mol} \%$ of the catalyst to give the corresponding biphenols $\mathbf{1}$ in good to excellent yields with up to $93 \%$ ee. The conversion of 1 to the corresponding phosphoric acids was achieved and utilized them in the hetero-Diels-Alder reaction. Further transformations of $\mathbf{1}$ were carried out and their use in asymmetric catalysis is currently under investigation.

\section{Experimental section}

\subsection{General information}

${ }^{1} \mathrm{H}-,{ }^{13} \mathrm{C}$-, and ${ }^{51} \mathrm{~V}-\mathrm{NMR}$ spectra were recorded with JEOL JMN ECS400 FT NMR, JNM ECA600 FT NMR or Bruker AVANCE II $\left({ }^{1} \mathrm{H}-\mathrm{NMR} 400,600\right.$ or $700 \mathrm{MHz},{ }^{13} \mathrm{C}-\mathrm{NMR} 100$, 150 or $\left.175 \mathrm{MHz},{ }^{51} \mathrm{~V}-\mathrm{NMR} 158 \mathrm{MHz}\right) .{ }^{1} \mathrm{H}-\mathrm{NMR}$ spectra are reported as follows: chemical shift in $\mathrm{ppm}$ relative to the chemical shift of $\mathrm{CHCl}_{3}$ at $7.26 \mathrm{ppm}$, integration, multiplicities (s = singlet, $\mathrm{d}=$ doublet, $\mathrm{q}=$ quartet, $\mathrm{t}=$ triplet, $\mathrm{m}=$ multiplet), and coupling constants $(\mathrm{Hz}) .{ }^{13} \mathrm{C}$-NMR spectra are reported in $\mathrm{ppm}$ relative to the central line of triplet for $\mathrm{CDCl}_{3}$ at $77 \mathrm{ppm} .{ }^{51} \mathrm{~V}$ NMR spectra were recorded with $\mathrm{VOCl}_{3}$ as an external standard (0 ppm). FT-MS spectra were obtained with LTQ Orbitrap XL (Thermo Fisher Scientific). ESI-MS spectra were obtained with JMS-T100LC (JEOL). FAB-MS spectra were obtained with JMS-700 (JEOL). Optical rotations were measured with JASCO P-1030 polarimeter. HPLC analyses were performed on a JASCO HPLC system (JASCO PU 980 pump and UV-975 UV/Vis detector) using a mixture of hexane and 2-propanol as eluents. FT-IR spectra were recorded on a JASCO FT-IR system (FT/IR4100). Mp was measured with SHIMADZU DSC-60. Column chromatography on $\mathrm{SiO}_{2}$ was performed with Kishida Silica Gel $(63-200 \mu \mathrm{m})$. Commercially available organic and inorganic compounds were used without further purification except for the solvent, which was distilled from sodium/benzophenone or $\mathrm{CaH}_{2}$.

\subsection{General procedure for coupling reactions using vanadium complexes}

A test tube was charged with a halogenated solvent $(1.0 \mathrm{~mL})$ solution of coupling substrate $(0.2 \mathrm{mmol})$ under air or $\mathrm{O}_{2}$ atmosphere. Vanadium catalyst $(0.01$ or $0.02 \mathrm{mmol}, 5$ or 10 mol \%) was added to the solution. The reaction mixture was stirred until the reaction had reached completion by monitoring with TLC analysis. Then the reaction mixture was directly purified by silica gel column chromatography eluting with ethyl acetate/n-hexane to give the coupling product.

(S)-1a ${ }^{4}: 85 \%$ ee, $[\alpha]_{\mathrm{D}}{ }^{22}+513.3$ (c $0.3, \mathrm{CHCl}_{3}$, for $97 \%$ ee); ${ }^{1} \mathrm{H}-$ $\operatorname{NMR}\left(\mathrm{CDCl}_{3}\right) \delta 8.52(\mathrm{~s}, 2 \mathrm{H}), 8.20(\mathrm{~d}, J=9.6 \mathrm{~Hz}, 2 \mathrm{H}), 7.99(\mathrm{~d}, J$ $=8.4 \mathrm{~Hz}, 2 \mathrm{H}), 7.73(\mathrm{~s}, 2 \mathrm{H}), 7.61(\mathrm{~d}, J=8.4 \mathrm{~Hz}, 2 \mathrm{H}), 7.47(\mathrm{~d}, J=$ $9.6 \mathrm{~Hz}, 2 \mathrm{H}), 7.39$ (t, $J=8.4 \mathrm{~Hz}, 2 \mathrm{H}), 5.21$ (brs, 2H); Daicel Chiralpak AD-H column, 2-propanol $/ n$-hexane $=3 / 17$, flow rate $1.0 \mathrm{~mL} / \mathrm{min}, 30.4 \mathrm{~min}$. ( $R$-isomer) and $41.9 \mathrm{~min}$. ( $S$-isomer).

$(S)-1 b^{5 a}:>99 \%$ ee, $[\alpha]_{\mathrm{D}}{ }^{23}-65.7$ (c $1.2, \mathrm{CHCl}_{3}$, for $>99 \%$ ee); ${ }^{1} \mathrm{H}-$ $\operatorname{NMR}\left(\mathrm{CDCl}_{3}\right) \delta 8.81(\mathrm{~d}, J=8.2 \mathrm{~Hz}, 2 \mathrm{H}), 8.75(\mathrm{~d}, J=8.2 \mathrm{~Hz}$, $2 \mathrm{H}), 8.46(\mathrm{~d}, J=8.2 \mathrm{~Hz}, 2 \mathrm{H}), 7.84-7.80(\mathrm{~m}, 2 \mathrm{H}), 7.74-7.71(\mathrm{~m}$, $2 \mathrm{H})$, 7.55-7.52 (m, 2H), 7.37-7.33 (m, 2H), 7.28-7.24 (m, 2H), 5.55 (brs, 2H); Daicel Chiralpak AD-H column, 2-propanol $/ n-$ hexane $=3 / 17$, flow rate $1.0 \mathrm{~mL} / \mathrm{min}, 21.0 \mathrm{~min}$. ( $R$-isomer) and 23.0 min. ( $S$-isomer).

$(R)-1 \mathrm{c}^{5 \mathrm{~m}}: 69 \%$ ee, $[\alpha]_{\mathrm{D}}{ }^{24}-59.1$ (c $0.8, \mathrm{CHCl}_{3}$, for $95 \%$ ee) ${ }^{1} \mathrm{H}-$ NMR $\left(\mathrm{CDCl}_{3}\right) \delta 8.09(\mathrm{~d}, J=8.7 \mathrm{~Hz}, 2 \mathrm{H}), 8.03(\mathrm{~d}, J=8.7 \mathrm{~Hz}$, 2H), 7.86-7.82 (m, 4H), $7.74(\mathrm{~d}, J=8.7 \mathrm{~Hz}, 2 \mathrm{H}), 7.45$ (d, $J=8.7$
$\mathrm{Hz}, 2 \mathrm{H}), 7.41-7.38$ (m, 2H), 6.96-6.92 (m, 2H), 5.03 (brs, 2H); Daicel Chiralpak OD-H column, 2-propanol $/ n$-hexane $=3 / 7$, flow rate $0.5 \mathrm{~mL} / \mathrm{min}, 16.4 \mathrm{~min}$. ( $S$-isomer) and $32.7 \mathrm{~min}$. ( $R$-isomer).

(S)-1d: $75 \%$ ee, $[\alpha]_{\mathrm{D}}{ }^{22}+213.5$ (c $0.1, \mathrm{CHCl}_{3}$, for $96 \%$ ee); ${ }^{1} \mathrm{H}-$ NMR $\left(\mathrm{CDCl}_{3}\right) \delta 9.80(\mathrm{~d}, J=8.4 \mathrm{~Hz}, 2 \mathrm{H}), 8.92(\mathrm{~d}, J=9.2 \mathrm{~Hz}$, $2 \mathrm{H}), 8.90(\mathrm{~d}, J=8.4 \mathrm{~Hz}, 2 \mathrm{H}), 8.19(\mathrm{~d}, J=9.2 \mathrm{~Hz}, 2 \mathrm{H}), 8.07-8.05$ (m, 2H), 7.69-7.59 (m, 6H), 7.39 (t, $J=7.8 \mathrm{~Hz}, 2 \mathrm{H}), 7.29$ (d, $J=$ $7.8 \mathrm{~Hz}, 2 \mathrm{H}), 6.32$ (brs, $2 \mathrm{H}) ;{ }^{13} \mathrm{C}-\mathrm{NMR}\left(\mathrm{CDCl}_{3}\right) \delta 152.6,133.1$, $132.2,131.7,130.7,129.9,129.1,128.4,127.9,127.0,126.5$, $125.7,124.9,124.7,123.8,121.1,120.3,109.8$; HRMS (ESITOF): calcd for $\mathrm{C}_{36} \mathrm{H}_{22} \mathrm{O}_{2} \mathrm{Na}[\mathrm{M}+\mathrm{Na}]^{+}$509.1517, found: $\mathrm{m} / \mathrm{z}$ 509.1511; IR (KBr): 3457, 2989, 1763, 1376, 1242, $1056 \mathrm{~cm}^{-1}$; Daicel Chiralpak AD-H column, 2-propanol $/ n$-hexane $=3 / 17$, flow rate $1.0 \mathrm{~mL} / \mathrm{min}, 11.9 \mathrm{~min}$. ( $S$-isomer) and $23.2 \mathrm{~min}$. (Risomer).

\subsection{Preparation of mononuclear vanadium complex (S)-5b}

A round bottomed flask was charged with 2-hydroxy-1naphthaldehyde $(1.46 \mathrm{mmol})$, which were prepared according to the known method, $(S)$-tert-leucine $(1.60 \mathrm{mmol})$, MS 3A $(0.73 \mathrm{~g})$ and $\mathrm{EtOH}(25 \mathrm{~mL})$. The reaction mixture was refluxed at $80{ }^{\circ} \mathrm{C}$ and consumption of the aldehyde substrate was monitored by TLC. After evaporation of EtOH, the residue was suspended in $\mathrm{CH}_{2} \mathrm{Cl}_{2}(15 \mathrm{~mL})$ and then $\mathrm{VOCl}_{3}(3.21 \mathrm{mmol})$ was added. The reaction mixture was stirred for $12 \mathrm{~h}$, and filtered by Celite to remove MS 3A. The filtrate was evaporated and the resulting black solid was dissolved in $\mathrm{MeOH}$ and the solvent was evaporated again. The residue was collected by filtration and washed sequentially with water and ether, and then dried in a vacuum to give $(S)-\mathbf{5 b}$ in $58 \%$ yield as a black powder.

(S)-5b: ${ }^{1} \mathrm{H}-\mathrm{NMR}\left(\mathrm{CD}_{3} \mathrm{OD}\right): \delta 9.48(\mathrm{~s}, 1 \mathrm{H}), 8.29(\mathrm{~d}, J=8.6 \mathrm{~Hz}$ 1H), 8.09 (d, $J=9.1 \mathrm{~Hz}, 1 \mathrm{H}), 7.87$ (d, $J=8.6 \mathrm{~Hz}, 1 \mathrm{H}), 7.63$ (t, $J$ $=7.2 \mathrm{~Hz}, 1 \mathrm{H}), 7.43(\mathrm{t}, J=7.2 \mathrm{~Hz}, 1 \mathrm{H}), 7.14(\mathrm{~d}, J=9.1 \mathrm{~Hz}, 1 \mathrm{H})$, $4.37(\mathrm{~s}, 1 \mathrm{H}), 1.28(\mathrm{~s}, 9 \mathrm{H}) ;{ }^{13} \mathrm{C}-\mathrm{NMR}\left(\mathrm{CD}_{3} \mathrm{OD}\right) ; \delta 180.3,165.8$, $163.3,138.7,134.9,130.5,130.04,130.00,125.4,121.4,120.9$, 112.6, 85.4, 38.3, 28.2; ${ }^{51} \mathrm{~V}-\mathrm{NMR}\left(\mathrm{CD}_{3} \mathrm{OD}\right): \delta-558.3$; HRMS (ESI-TOF): calcd for $\mathrm{C}_{18} \mathrm{H}_{20} \mathrm{NO}_{5} \mathrm{VNa} \quad[\mathrm{M}-\mathrm{OH}+\mathrm{OMe}+\mathrm{Na}]^{+}$ 404.0678, found: $\mathrm{m} / \mathrm{z}$ 404.0674; IR (KBr): 3233, 2961, 1672, $1612,1335,971 \mathrm{~cm}^{-1}$.

\subsection{Preparation of organocatalyst (S)-6d}

The organocatalyst (S)-6d was prepared according to the literature method. ${ }^{8 \mathrm{a}}$

(S)-6d: $[\alpha]_{\mathrm{D}}{ }^{22}+822.0$ (c $0.2, \mathrm{CHCl}_{3}$, for $96 \%$ ee); ${ }^{1} \mathrm{H}-\mathrm{NMR}$ $\left(\mathrm{CDCl}_{3}\right) \delta 9.71(\mathrm{~d}, \mathrm{~J}=7.6 \mathrm{~Hz}, 2 \mathrm{H}), 8.75-8.63(\mathrm{~m}, 4 \mathrm{H}), 7.90-7.19$ $(\mathrm{m}, 14 \mathrm{H}) ;{ }^{13} \mathrm{C}-\mathrm{NMR}\left(\mathrm{CDCl}_{3}\right) \delta 146.68,146.62,143.2,140.7$, $133.0,131.61,131.25,129.8,129.2,128.5,128.2,127.6,127.3$, 126.7, 126.4, 125.9, 125.0, 123.5, 123.0, 122.6, 120.7; ${ }^{31} \mathrm{P}-\mathrm{NMR}$ $\left(\mathrm{CDCl}_{3}\right) \delta 1.62$; HRMS (ESI-TOF): calcd for $\mathrm{C}_{36} \mathrm{H}_{21} \mathrm{O}_{4} \mathrm{PNa}$ $[\mathrm{M}+\mathrm{Na}]^{+}$571.1070, found: $\mathrm{m} / \mathrm{z}$ 571.1072; IR (KBr): 3438, 2938, $1744,1365,1211,1090 \mathrm{~cm}^{-1}$.

6.5. General procedure for direct organocatalytic enantioselective Diels-Alder reaction of 2-cyclohexenone (7) and aldimines $\boldsymbol{8}$

2-Cyclohexenone (7) $(0.07 \mathrm{~mL}, 0.73 \mathrm{mmol})$ was added to a vial containing aldimines $8(0.073 \mathrm{mmol})$ and a catalytic amount of phosphoric acid $6(5 \mathrm{~mol} \%)$ in toluene $(0.27 \mathrm{~mL})$ at $\mathrm{rt}$. After vigorously stirring the mixture for $72 \mathrm{~h}$, the reaction mixture was directly purified by column chromatography on silica gel to afford 9.

endo-9c: $34 \%$ ee, $[\alpha]_{\mathrm{D}}{ }^{20}+32.7$ (c $0.6, \mathrm{CHCl}_{3}$, for $34 \%$ ee); ${ }^{1} \mathrm{H}-$ NMR $\left(\mathrm{CDCl}_{3}\right) \delta$ 7.83-7.74 (m, 4H), 7.45-7.39 (m, 3H), $6.75(\mathrm{dd}$, $J=6.6,2.2 \mathrm{~Hz}, 2 \mathrm{H}), 6.66(\mathrm{dd}, J=6.6,3.2 \mathrm{~Hz}, 2 \mathrm{H}), 4.72(\mathrm{~s}, 1 \mathrm{H})$, 
$4.50(\mathrm{~s}, 1 \mathrm{H}), 3.70(\mathrm{~s}, 3 \mathrm{H}), 2.88-2.83(\mathrm{~m}, 2 \mathrm{H}), 2.49(\mathrm{dd}, J=18.8$, $2.7 \mathrm{~Hz}, 1 \mathrm{H}), 2.37-2.29(\mathrm{~m}, 1 \mathrm{H}), 2.25-2.15(\mathrm{~m}, 1 \mathrm{H}), 2.11-2.03(\mathrm{~m}$, $1 \mathrm{H}), 1.81-1.74(\mathrm{~m}, 1 \mathrm{H}) ;{ }^{13} \mathrm{C}-\mathrm{NMR}\left(\mathrm{CDCl}_{3}\right) \delta 211.8,152.1,142.5$, $139.6,133.6,133.0,128.9,128.1,127.7,126.1,125.8,124.6$, $123.8,114.8,114.6,66.5,55.6,52.0,49.3,46.2,22.8,22.3$; HRMS (ESI-TOF): calcd for $\mathrm{C}_{24} \mathrm{H}_{23} \mathrm{NO}_{2} \mathrm{Na}[\mathrm{M}+\mathrm{Na}]^{+}$380.1621, found: $\mathrm{m} / \mathrm{z}$ 380.1621; IR (KBr): 3422, 2948, 2372, 1721, 1510, $1248 \mathrm{~cm}^{-1}$; Daicel Chiralpak AD-H column, 2-propanol/n-hexane $=1 / 20$, flow rate $1.0 \mathrm{~mL} / \mathrm{min}, 28.8 \mathrm{~min}$. (minor isomer) and 39.8 min. (major isomer).

\subsection{Transformation of (S)-1b}

\subsubsection{Preparation of (S)-10}

To a $5 \mathrm{~mL}$ round-bottomed flask at $\mathrm{rt}$ was added $(S)-\mathbf{1 b}(50 \mathrm{mg}$, $0.13 \mathrm{mmol})$, and $\mathrm{PtO}_{2}(31.7 \mathrm{mg}, 0.12 \mathrm{mmol})$ in glacial acetic acid $(1.5 \mathrm{~mL})$. The flask was furnished with a stream of hydrogen (1 atm) at rt. After stirring for 5 days, the reaction mixture was filtered by Celite to remove $\mathrm{PtO}_{2}$. The mother liquid was washed with $\mathrm{H}_{2} \mathrm{O}$, and then evaporated. The crude was purified by column chromatography to give $(S)-\mathbf{1 0}$ in $80 \%$ yield (42 mg, 0.10 mmol) as a pale brown solid.

(S)-10: Mp 177-179 ${ }^{\circ} \mathrm{C}$; $>99 \%$ ee, $[\alpha]_{\mathrm{D}}^{21}-32.9$ (c $0.5, \mathrm{CHCl}_{3}$, for $>99 \%$ ee); ${ }^{1} \mathrm{H}-\mathrm{NMR}\left(\mathrm{CDCl}_{3}\right): \delta 4.60$ (brs, $\left.2 \mathrm{H}\right), 2.78-2.43(\mathrm{~m}$, $12 \mathrm{H}), 2.35-2.08(\mathrm{~m}, 4 \mathrm{H}), 1.94-1.54(\mathrm{~m}, 16 \mathrm{H}) ;{ }^{13} \mathrm{C}-\mathrm{NMR}\left(\mathrm{CDCl}_{3}\right)$ : $\delta 149.1,137.3,132.6,127.7,121.7,115.6,27.7,26.7,26.2,23.7$, 23.3, 23.1, 22.9, 22.2; HRMS (ESI-TOF): calcd for $\mathrm{C}_{28} \mathrm{H}_{34} \mathrm{O}_{2} \mathrm{Na}$ $[\mathrm{M}+\mathrm{Na}]^{+}$425.2451, found: $\mathrm{m} / \mathrm{z}$ 425.2452; IR (KBr): 3517, 2928, $2860,1438,1301,1212 \mathrm{~cm}^{-1}$.

\subsubsection{Preparation of (S)-11}

To a solution of $(S)-\mathbf{1 b}(1.0 \mathrm{~g}, 2.58 \mathrm{mmol})$ in anhydrous acetone $(20 \mathrm{~mL})$ was added to anhydrous $\mathrm{K}_{2} \mathrm{CO}_{3}(1.43 \mathrm{~g}, 10.4$ mmol) and methyl iodide (1.83 g, $12.9 \mathrm{mmol})$. The reaction mixture was heated at $50{ }^{\circ} \mathrm{C}$ under Ar atmosphere for $4 \mathrm{~h}$. After cooling to $\mathrm{rt}$, the volatiles were removed in vacuum and the residues were washed with $\mathrm{CH}_{2} \mathrm{Cl}_{2}$. The organic layers were dried over anhydrous $\mathrm{Na}_{2} \mathrm{SO}_{4}$ and then evaporated. The crude was purified by column chromatography to give (S)-11 in $80 \%$ yield $(0.85 \mathrm{~g}, 2.06 \mathrm{mmol})$ as a white solid.

$(S)-11^{5 \mathrm{a}}: \mathrm{Mp} 255-257{ }^{\circ} \mathrm{C} ;>99 \%$ ee, $[\alpha]_{\mathrm{D}}{ }^{25}+35.8$ (c 1.0, $\mathrm{CHCl}_{3}$, for $>99 \%$ ee); ${ }^{1} \mathrm{H}-\mathrm{NMR}\left(\mathrm{CDCl}_{3}\right) \delta 8.84(\mathrm{~d}, J=8.1 \mathrm{~Hz}, 2 \mathrm{H}), 8.77$ $(\mathrm{d}, J=8.3 \mathrm{~Hz}, 2 \mathrm{H}), 8.34(\mathrm{~d}, J=9.5 \mathrm{~Hz}, 2 \mathrm{H}), 7.80-7.70(\mathrm{~m}, 4 \mathrm{H})$, 7.58-7.55 (m, 2H), 7.34-7.33 (m, 4H), 3.57 (s, 6H); ${ }^{13} \mathrm{C}-\mathrm{NMR}$ $\left(\mathrm{CDCl}_{3}\right) \delta 152.7,132.9,132.0,128.2,128.1,127.2,126.9$ х 2 , $126.8,125.5,123.6,122.9,122.7,122.3,61.2$.

\subsubsection{Preparation of (S)-12}

To a solution of $(S)-\mathbf{1 1}(50 \mathrm{mg}, 0.12 \mathrm{mmol})$ in $\mathrm{MeCN}(2 \mathrm{~mL})$ was gradually added to NBS (107 $\mathrm{mg}, 0.6 \mathrm{mmol})$. The reaction mixture was stirred for $2 \mathrm{~h}$ under reflux conditions. The volatiles were removed in vacuum and the residues were washed with water, brine and $\mathrm{CH}_{2} \mathrm{Cl}_{2}$. The organic layers were dried over anhydrous $\mathrm{Na}_{2} \mathrm{SO}_{4}$ and then evaporated. The crude was purified by column chromatography to give $(S)-\mathbf{1 2}$ in quantitative yield (68 mg, $0.12 \mathrm{mmol}$ ).

(S)-12: Mp 282-284 ${ }^{\circ} \mathrm{C}$; $>99 \%$ ee, $[\alpha]_{\mathrm{D}}{ }^{23}-17.4$ (c 1.0, $\mathrm{CHCl}_{3}$, for $>99 \%$ ee); ${ }^{1} \mathrm{H}-\mathrm{NMR}\left(\mathrm{CDCl}_{3}\right) \delta 8.89(\mathrm{~d}, J=2.0 \mathrm{~Hz}, 2 \mathrm{H}), 8.74-$ $8.72(\mathrm{~m}, 2 \mathrm{H}), 8.33-8.32(\mathrm{~m}, 2 \mathrm{H}), 7.79-7.74(\mathrm{~m}, 4 \mathrm{H}), 7.43-7.39$ $(\mathrm{m}, 2 \mathrm{H}), 7.17-7.13(\mathrm{~m}, 2 \mathrm{H}), 3.55(\mathrm{~s}, 6 \mathrm{H}) ;{ }^{13} \mathrm{C}-\mathrm{NMR}\left(\mathrm{CDCl}_{3}\right) \delta$ $153.2,131.4,131.0,130.2,129.8,128.3,128.2,127.7,127.6$, 125.6, 123.7, 123.0, 121.3, 120.1, 61.3; HRMS (ESI-TOF): calcd for $\mathrm{C}_{30} \mathrm{H}_{20} \mathrm{Br}_{2} \mathrm{O}_{2} \mathrm{Na}[\mathrm{M}+\mathrm{Na}]^{+}$594.9702, found: $\mathrm{m} / \mathrm{z}$ 594.9702; IR (KBr): 3071, 2947, 1588, 1428, 1118, $1086 \mathrm{~cm}^{-1}$.

\subsubsection{Preparation of (S)-13}

To a solution of $(S)-\mathbf{1 2}(200 \mathrm{mg}, 0.36 \mathrm{mmol})$ in $\mathrm{CH}_{2} \mathrm{Cl}_{2}(4 \mathrm{~mL})$ was slowly added to $\mathrm{BBr}_{3}\left(1 \mathrm{M}\right.$ solution in $\left.\mathrm{CH}_{2} \mathrm{Cl}_{2}\right)(0.76 \mathrm{~mL}$, $0.76 \mathrm{mmol})$ at $0{ }^{\circ} \mathrm{C}$ under $\mathrm{Ar}$ atmosphere. The reaction mixture was stirred for overnight. After addition of water $(1 \mathrm{~mL})$, the mixture was extracted with $\mathrm{CH}_{2} \mathrm{Cl}_{2}$. The organic layers were washed with water, brine and dried over anhydrous $\mathrm{Na}_{2} \mathrm{SO}_{4}$. After the evaporation, (S)-13 was obtained in 70\% yield $(130 \mathrm{mg}$, $0.25 \mathrm{mmol})$ as a white solid.

(S)-13: Mp 303-305 ${ }^{\circ} \mathrm{C}$; $>99 \%$ ee, $[\alpha]_{\mathrm{D}}^{25}-49.6$ (c $0.5, \mathrm{CHCl}_{3}$, for $>99 \%$ ee); ${ }^{1} \mathrm{H}-\mathrm{NMR}\left(\mathrm{CDCl}_{3}\right) \delta 8.85(\mathrm{~d}, J=2.0 \mathrm{~Hz}, 2 \mathrm{H}), 8.70(\mathrm{~d}$, $J=8.3 \mathrm{~Hz}, 2 \mathrm{H}), 8.44(\mathrm{~d}, J=8.3 \mathrm{~Hz}, 2 \mathrm{H}), 7.85-7.81(\mathrm{~m}, 2 \mathrm{H})$, 7.76-7.72 (m, 2H), $7.41(\mathrm{dd}, J=8.8,2.0 \mathrm{~Hz}, 2 \mathrm{H}), 7.06(\mathrm{~d}, J=8.8$ $\mathrm{Hz}, 2 \mathrm{H}), 5.58(\mathrm{~s}, 2 \mathrm{H}) ;{ }^{13} \mathrm{C}-\mathrm{NMR}\left(\mathrm{CDCl}_{3}\right) \delta 149.9,131.0,130.8$, $130.2,128.8,128.7,127.7,126.7,125.9,125.1,123.7,122.8$, 119.2, 106.3; HRMS (ESI-TOF): calcd for $\mathrm{C}_{28} \mathrm{H}_{14} \mathrm{Br}_{2} \mathrm{O}_{2} \mathrm{Na}$ [M$\left.\mathrm{H}_{2}+\mathrm{Na}\right]^{+}$564.9233, found: $\mathrm{m} / \mathrm{z}$ 564.9231; IR (KBr): 3488, 1591, $1491,1423,1207,1002,672 \mathrm{~cm}^{-1}$.

\subsubsection{Preparation of $(S)-14$}

To a solution of $(S)-\mathbf{1 2}(50 \mathrm{mg}, 0.09 \mathrm{mmol})$ in DME $(1.5 \mathrm{~mL})$ and $2 \mathrm{M}$ aq. $\mathrm{Na}_{2} \mathrm{CO}_{3}(0.25 \mathrm{~mL})$ was added to $\mathrm{PhB}(\mathrm{OH})_{2}(27 \mathrm{mg}$, $0.22 \mathrm{mmol})$ and $\mathrm{Pd}\left(\mathrm{PPh}_{3}\right)_{4}(10 \mathrm{mg}, 0.009 \mathrm{mmol})$ under $\mathrm{Ar}$ atmosphere. The reaction mixture was heated at $80{ }^{\circ} \mathrm{C}$ for $8 \mathrm{~h}$. After filtration, the mixture was extracted with $\mathrm{CH}_{2} \mathrm{Cl}_{2}$. The organic layers were washed with water, brine and dried over anhydrous $\mathrm{Na}_{2} \mathrm{SO}_{4}$ and then evaporated. The crude was purified by column chromatography to give $(S)-14$ in $79 \%$ yield (39 mg, $0.07 \mathrm{mmol}$ ) as a white solid.

(S)-14: $>99 \%$ ee, $[\alpha]_{\mathrm{D}}{ }^{22}-2.1$ (c $0.5, \mathrm{CHCl}_{3}$, for $>99 \%$ ee); ${ }^{1} \mathrm{H}-$ NMR $\left(\mathrm{CDCl}_{3}\right) \delta 9.00(\mathrm{~d}, J=1.7 \mathrm{~Hz}, 2 \mathrm{H}), 8.96-8.93(\mathrm{~m}, 2 \mathrm{H})$, $8.39(\mathrm{~m}, 2 \mathrm{H}), 7.83-7.74(\mathrm{~m}, 8 \mathrm{H}), 7.61-7.58(\mathrm{~m}, 2 \mathrm{H}), 7.52-7.34$ $(\mathrm{m}, 8 \mathrm{H}), 3.63(\mathrm{~s}, 6 \mathrm{H}) ;{ }^{13} \mathrm{C}-\mathrm{NMR}\left(\mathrm{CDCl}_{3}\right) \delta 152.8,141.3,138.3$, $132.1,128.9,128.5,128.4,127.5,127.3,127.1,126.4,123.7$, $123.0,122.1,121.2,120.8,115.3,61.4$ (One peak is merged with other peak.); HRMS (ESI-TOF): calcd for $\mathrm{C}_{42} \mathrm{H}_{30} \mathrm{O}_{2} \mathrm{Na}[\mathrm{M}+\mathrm{Na}]^{+}$ 589.2138, found: $\mathrm{m} / \mathrm{z}$ 589.2140; IR (KBr): 3416, 2841, 1593, $1227,1080,700 \mathrm{~cm}^{-1}$.

\subsubsection{Preparation of (S)-15}

To a solution of $(S)-14(40 \mathrm{mg}, 0.071 \mathrm{mmol})$ in $\mathrm{CH}_{2} \mathrm{Cl}_{2}(4 \mathrm{~mL})$ was slowly added to $\mathrm{BBr}_{3}\left(1 \mathrm{M}\right.$ solution in $\left.\mathrm{CH}_{2} \mathrm{Cl}_{2}\right)(0.18 \mathrm{~mL}$, $0.18 \mathrm{mmol})$ at $0{ }^{\circ} \mathrm{C}$ under $\mathrm{Ar}$ atmosphere. The reaction mixture was stirred for overnight. After addition of water $(1 \mathrm{~mL})$, the mixture was extracted with $\mathrm{CH}_{2} \mathrm{Cl}_{2}$. The organic layers were washed with water, brine and dried over anhydrous $\mathrm{Na}_{2} \mathrm{SO}_{4}$. After the evaporation, (S)-15 was obtained in quantitative yield (38 $\mathrm{mg}, 0.071 \mathrm{mmol}$ ) as a white solid.

(S)-15: Mp 184-186 ${ }^{\circ} \mathrm{C} ;>99 \%$ ee, $[\alpha]_{\mathrm{D}}^{25}-51.7$ (c $0.5, \mathrm{CHCl}_{3}$, for $>99 \%$ ee); ${ }^{1} \mathrm{H}-\mathrm{NMR}\left(\mathrm{CDCl}_{3}\right) \delta 8.96(\mathrm{~d}, J=1.7 \mathrm{~Hz}, 2 \mathrm{H}), 8.92-$ $8.90(\mathrm{~m}, 2 \mathrm{H}), 8.49$ (dd, $J=4.0,1.7 \mathrm{~Hz}, 2 \mathrm{H}), 7.87-7.83(\mathrm{~m}, 2 \mathrm{H})$, 7.77-7.72 (m, 6H), 7.63-7.59 (m, 2H), 7.50-7.48 (m, 4H), 7.40$7.36(\mathrm{~m}, 4 \mathrm{H}), 5,61(\mathrm{~s}, 2 \mathrm{H}) ;{ }^{13} \mathrm{C}-\mathrm{NMR}\left(\mathrm{CDCl}_{3}\right) \delta 149.6,141.3$, $137.7,132.1,130.9,128.9,128.3,127.5,127.3,127.1,125.6$, $125.15,125.13,123,7,122.8,121.5,107.0$ (One peak is merged with other peak.); HRMS (ESI-TOF): calcd for $\mathrm{C}_{40} \mathrm{H}_{24} \mathrm{O}_{2} \mathrm{Na}$ [M$\left.\mathrm{H}_{2}+\mathrm{Na}\right]^{+}$559.1669, found: $\mathrm{m} / \mathrm{z}$ 559.1667; IR (KBr): 3416, 2841, $1593,1227,1080,700 \mathrm{~cm}^{-1}$.

\section{Acknowledgments}

This work was supported by the CREST project of the Japan Science and Technology Corporation (JST), Grant-in-Aid for Scientific Research on Innovative Areas "Advanced Molecular 
Transformations by Organocatalysts" from the Ministry of Education, Culture, Sports, Science and Technology (MEXT), and the JSPS Japanese-German Graduate Externship, Japan. We thank the Deutsche Forschungsgemeinschaft (scholarship for S.B., the International Research Training Group "Selectivity in Chemo- and Biocatalysis"-Seleca, Germany). We acknowledge the technical staff of the Comprehensive Analysis Center of ISIR, Osaka University (Japan).

\section{References and notes}

1. (a) Pu L. Chem. Rev. 1998, 98, 2405; (b) Brunel, J. M. Chem. Rev. 2007, 107, PR1; (c) Shibasaki, M.; Matsunaga, S. BINOL, In Privileged Chiral Ligands and Catalysts, Q.-L. Zhou ed., Wiley-VCH Verlag GmbH \& Co. KGaA, Weinheim, Germany, 2011; (d) Allen, S. A.; Walvoord, R. R.; Padilla-Salinas, R.; Kozlowski, M. C. Chem. Rev. 2013, 113, 6234.

2. Recent reviews and reports on asymmetric oxidative coupling of 2naphthols, see: (a) Punniyamurthy, T. Rout, L. Coord. Chem. Rev. 2008, 252, 134; (b) Takizawa, S.; Katayama, T.; Sasai, H. Chem. Commun. 2008, 4113; (c) Kozlowski, M. C.; Morgan, B. J.; Linton, E. C. Chem. Soc. Rev. 2009, 38, 3193; (d) Takizawa, S. Chem. Pharm. Bull. 2009, 57, 1179; (e) Wang, H. Chirality 2010, 22, 827; (f) O'Brien, E. M.; Morgan, B. J.; Mulrooney, C. A.; Carroll, P. J.; Kozlowski, M. C. J. Org. Chem. 2010, 75, 57; (g) Egami, H; Matsumoto, K.; Oguma, T.; Kunisu, T.; Katsuki, K. J. Am. Chem. Soc. 2010, 132, 13633; (h) Podlesny, E. E.; Kozlowski, M. C. Org. Lett. 2012, 14, 1408; (i) Podlesny, E. E.; Kozlowski, M. C. J. Org. Chem. 2013, 78, 466.

3. (a) Hon, S.-W.; Li, C.-H.; Kuo, J.-H.; Barhate, N. B.; Liu, Y.-H.; Wang, Y.; Chen, C.-T. Org. Lett. 2001, 3, 869; (b) Chu, C.-Y.; Hwang, D.-R.; Wang, S.-K.; Uang, B.-J. Chem. Commun. 2001, 980; (c) Barhate, N. B.; Chen, C.-T. Org. Lett. 2002, 4, 2529; (d) Luo, Z.; Liu, Q.; Gong, L.; Cui, X.; Mi, A.; Jiang, Y. Chem. Commun. 2002, 914; (e) Luo, Z.; Liu, Q.; Gong, L.; Cui, X.; Mi, A.; Jiang, Y. Angew. Chem., Int. Ed. 2002, 41, 4532; (f) Chu, C.-Y.; Uang, B.-J. Tetrahedron: Asymmetry 2003, 14, 53; (g) Somei, H.; Asano, Y.; Yoshida, T.; Takizawa, S.; Yamataka, H.; Sasai, H. Tetrahedron Lett. 2004, 45, 1841; (h) Tada, M.; Taniike, T.; Kantam, L. K.; Iwasawa, Y. Chem. Commun. 2004, 2542; (i) Tada, M.; Kojima, N.; Izumi, Y.; Taniike, T.; Iwasawa, Y. J. Phys. Chem. B 2005, 109, 9905; (j) Habaue, S.; Murakami, S.; Higashimura, H. J. Polym. Sci. Part A: Polym. Chem. 2005, 43, 5872; (k) Tada, M.; Iwasawa, Y. Chem. Commun. 2006, 2833; (1) Guo, Q.-X.; Wu, Z.-J.; Luo, Z.-B.; Liu, Q.-Z.; Ye, J.-L.; Luo,
S.-W.; Cun, L.-F.; Gong, L.-Z. J. Am. Chem. Soc. 2007, 129, 13927; (m) Takizawa, S.; Katayama, T.; Kameyama, C.; Onitsuka, K.; Suzuki, T.; Yanagida, T.; Kawai, T.; Sasai, H. Chem. Commun. 2008, 1810; (n) Takizawa, S.; Katayama, T.; Somei, H.; Asano, Y.; Yoshida, T.; Kameyama, C.; Rajesh, D.; Onitsuka, K.; Suzuki, T.; Mikami, M.; Yamataka, H.; Jayaprakash, D.; Sasai, H. Tetrahedron 2008, 64, 3361; (o) Takizawa, S.; Rajesh, D.; Katayama, T.; Sasai, H. Synlett 2009, 1667.

4. (a) Bell, F.; Waring, D. H. J. Chem. Soc. 1949, 267; (b) Zhang, S.; Wang, Y.; Song, Z.; Nakajima, K.; Takahashi, T. Chem. Lett. 2013, 42, 697.

5. (a) Yamamoto, K.; Fukushima, H.; Okamoto, Y.; Hatada, K.; Nakazaki, M. J. Chem. Soc. Chem. Commun. 1984, 1111; (b) Yamamoto, K.; Fukushima, H.; Nakazaki, M. J. Chem. Soc. Chem. Commun. 1984, 1490; (c) Yamamoto, K.; Noda, K.; Okamoto, Y. J. Chem. Soc. Chem. Commun. 1985, 1065; (d) Yamamoto, K.; Fukushima, H.; Yumioka, H.; Nakazaki, M. Bull. Chem. Soc. Jpn. 1985, 58, 3633; (e) Toda, F.; Tanaka, K. Tetrahedron Lett. 1988, 29, 1807; (f) Toda, F.; Tanaka, K.; Nassimbeni, L.; Niven, M. Chem. Lett. 1988, 8, 1371; (g) Yamamura, K.; Ono, S.; Ogoshi, H.; Masuda, H.; Kuroda, Y. Synlett 1989, 18; (h) Smrcina, M.; Polakova, J.; Vyskocil, S.; Kocovsky, P. J. Org. Chem. 1993, 58, 4534; (i) Osa, T.; Kashiwagi, Y.; Yanagisawa, Y.; Bobbitt, J. M. J. Chem. Soc. Chem. Commun. 1994, 2535; (j) Koike, N.; Hattori, T.; Miyano, S. Tetrahedron: Asymmetry 1994, 5, 1899; (k) Dore, A.; Fabbri, D.; Gladiali, S.; Valle, G. Tetrahedron: Asymmetry 1995, 6, 779; (1) Lin, Y.; Chien, L. C. Tetrahedron: Asymmetry 1998, 9, 63; (m) Nakano, K.; Hidehira, Y.; Takahashi, K.; Hiyama, T.; Nozaki, K. Angew. Chem. Int. Ed. 2005, 44, 7136; (n) Aydin, J.; Kumar, K. S.; Sayah, M. J.; Wallner, O. A.; Szabo, K. J. Org. Chem. 2007, 72, 4689; (o) Hu, G.; Holmes, D.; Gendhar, B. F.; Wulff, W. D. J. Am. Chem. Soc. 2009, 131, 14355.

6. (a) Fu, J.-M.; Snieckus, V. Can. J. Chem. 2000, 78, 905; (b) Karikomi, M.; Yamada, M.; Ogawa, Y.; Houjou, H.; Seki, K.; Hiratani, K.; Haga, K.; Uyehara, T. Tetrahedron Lett. 2005, 46, 5867.

7. Selected reviews for chiral phosphoric acids as organocatalysts, see: (a) Akiyama, T.; Itoh, J.; Fuchibe, K. Adv. Synth. Catal. 2006, 348, 999; (b) Terada, M. Curr. Org. Chem. 2011, 15, 2227; (c) Rueping, M.; Kuenkel, A.; Atodiresei, I. Chem. Soc. Rev. 2011, 40, 4539; (d) Yu, J.; Shi, F.; Gong, L.-Z. Acc. Chem. Res. 2011, 44, 1156.

8. (a) Liu, H.; Cun, L.-F.; Mi, A.-O.; Jing, Y.-Z.; Gong, L.-Z. Org. Lett. 2006, 8, 6023; (b) Rueping, M.; Azap, C. Angew. Chem. Int. Ed. 2006, 45,7832 .

9. Kim, J. G.; Camp, E. H.; Walsh, P. J. Org. Lett. 2006, 8, 4413. 


\section{Graphical Abstract}

To create your abstract, type over the instructions in the template box below.

Fonts or abstract dimensions should not be changed or altered.

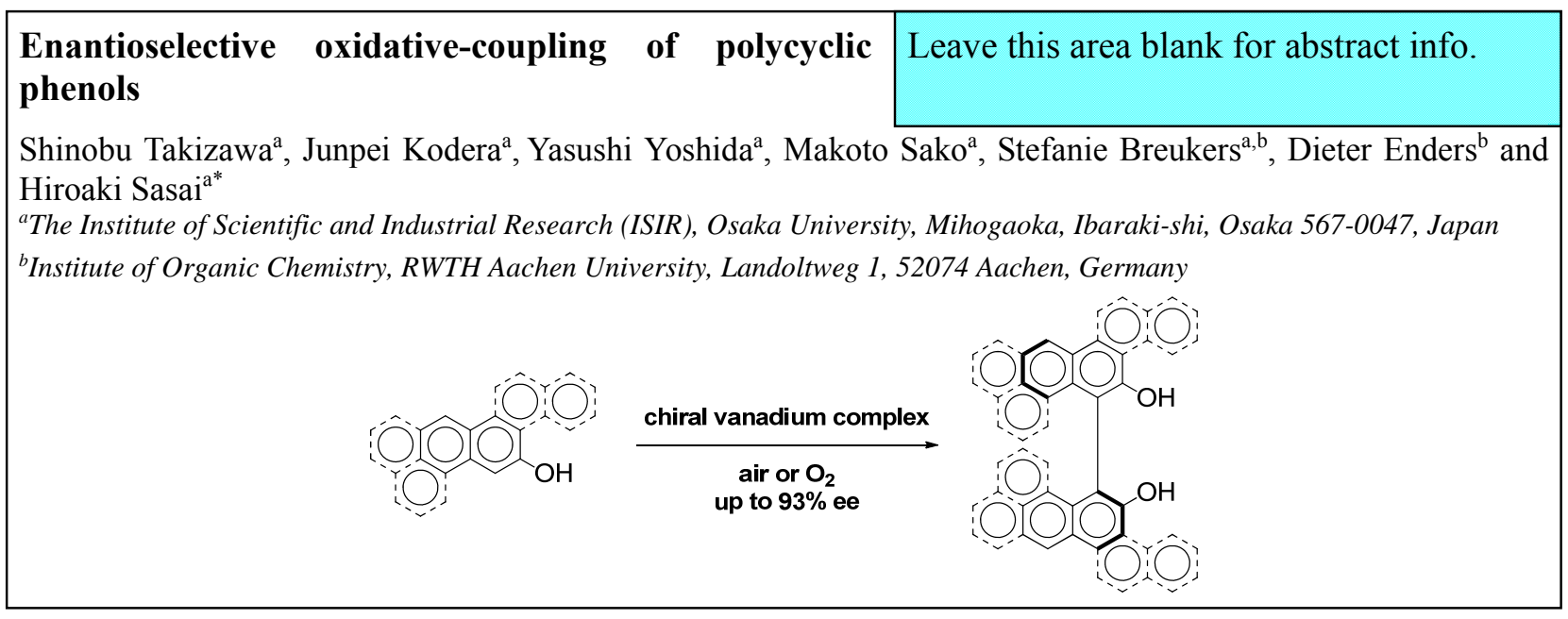

